
ANDREJ KÓŇ̃ 1

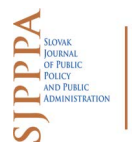
sipppa.fsvucm.sk ISSN 1339-7826 (online)

\title{
THE CRISIS IS A NATURAL PART OF ECONOMIC DEVELOPMENT, IT IS NECESSARY TO LEARN TO FACE IT ${ }^{2}$
}

\begin{abstract}
Europe has the strongest and largest tourism in the world. As in times of economic prosperity, the industry can prosper, in the case of a change in the economic environment as a result of a crises, it is hit hard and the tourism industry throughout the European Union is suffering billions of euros in damage. It is the case of all post-communist countries and also in Slovak Republic. The effects of such fluctuations are all the greater for the country's GDP because they do not have contingency plans in place and solutions are often chaotic or implemented too late. The article assesses the impact of several crises, including the current one associated with COVID-19 and predicts a possible approach to mitigate the consequences of the crisis and at the same time better manage the future crisis.
\end{abstract}

Key words: smart city; COVID; tourism; gross domestic product; municipality

\section{INTRODUCTION}

As a result of the financial and economic crisis with the start of 2008 year and downturn in economic development, there was also a decline of tourism not only in Slovakia, but also at the global level. After four decades (2003-2007) of steady economic growth, expectations of a slump in tourism have been more embarrassing than negative. Globally, 2008 year recorded an increase in tourism 1,9\% in compared to the year 2007. Also, income from global tourism recorded an increase by $10,2 \%$ in 2008 compared to 2007. The average increase of foreign tourists in

1 Mgr. Andrej Kóňa, PhD., Department of Public Administration, Faculty of Social Sciences, University of Ss. Cyril, and Methodius, Bučianska 4/A, 91701 Trnava, Slovakia, e-mail: andrej. kona@ucm.sk

2 This contribution was supported by the project KEGA 001UCM-4/2019 "Dynamika premien verejnej správy SR". 
Slovakia was in the period from 2003 to 2007 was 5,3\%. In the following years 2008 and 2009 this value decreased to $4,9 \%$ (OECD, 2010, 2012).

\section{THE IMPACT OF CRISES ON THE DEVELOPMENT OF TOURISM}

In the Central and Eastern Europe started the rapid expansion of tourism began in the early 1990s after the fall of the Berlin wall. Growth was relatively strong first decade, especially in the Czech Republic and Slovakia.

Graf 1: Development of \% share of tourism in Slovak GDP

\section{Slovak Republic}

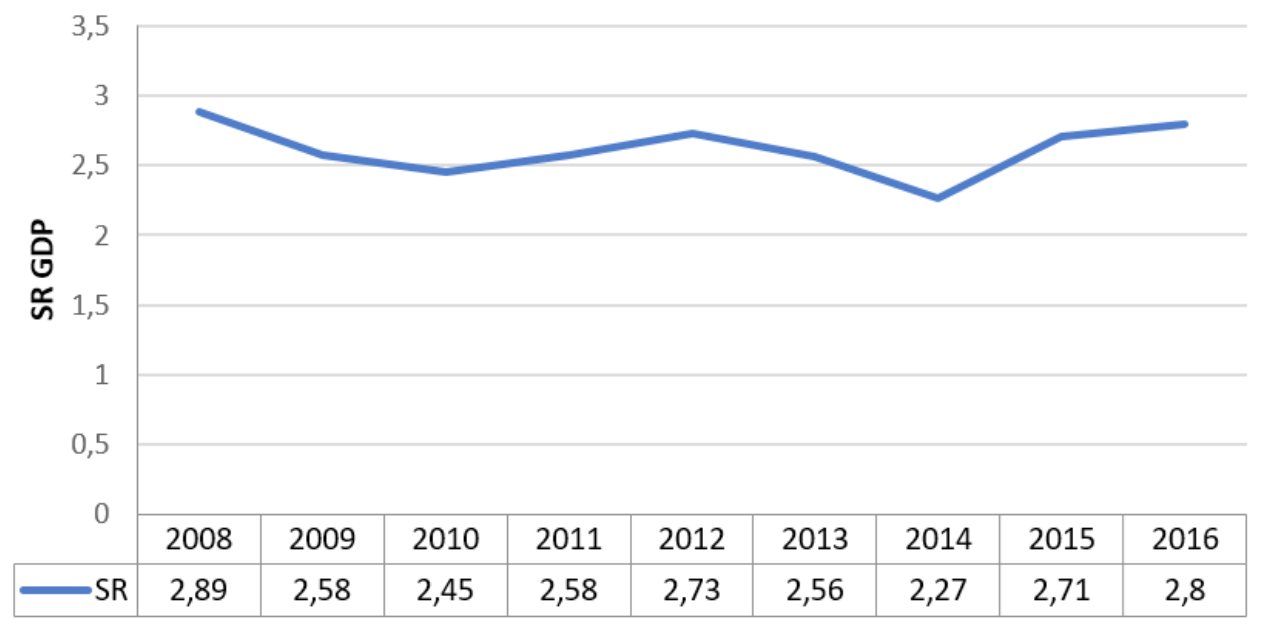

Source: OECD Tourism Statistics, 2020

Markets, technologies and communications have gradually taken on an international dimension, making the globalization of a economy a reality for these countries as well. Deeper liberalization of international trade approaches and the removal of barriers to international trade have allowed the global crisis to spread very rapidly among the world's financial institutions between 2008-2010 years, triggering the worst global recession in last 60 years. These principles also facilitated the rapid spread of non-financial threats to global business, such as SARS and H1n1 influenza. In this new global world tourism must also work to deal with these crises. 
Graf 2: World international tourist arrivals and GDP growth, 1989-08

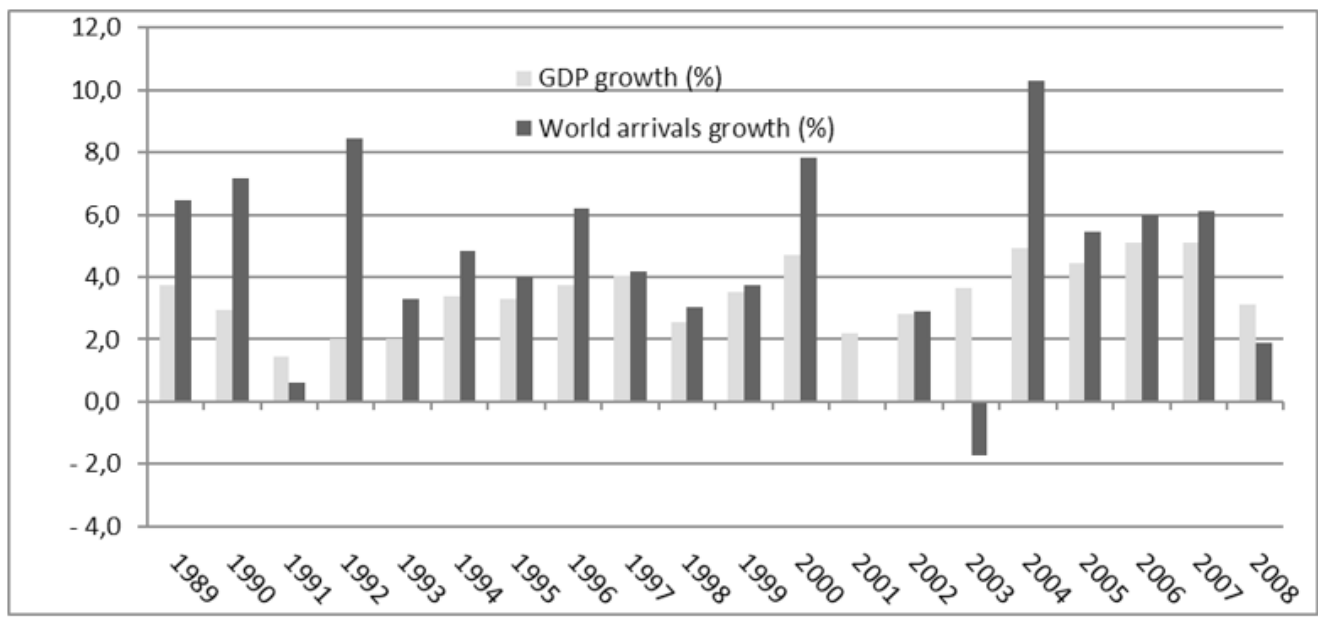

Source: OECD 2010, EUROSTAT 2020.

In 2010 revenues from international tourism amounted to 1684,4 million euros, which is $0,6 \%$ more than in the previous year, representing $2,5 \%$ of GDP (2,6\% in 2009). Expenditures Slovak citizens traveling abroad in 2010 reached a total of 1470,7 mil. EUR, which is $2,2 \%$ less than in 2009 year.

Crises and disasters are a major problem for the economic policy due to the rapidly changing positive developoment of tourism in a negative position and the unpredictable consequences of these situations for employment and profitability. Stocks of hotels, airlines and attractions are perishable and, unlike agriculture products and manufactured goods cannot be stored. If they are not sold, the enterprise will not receive revenue from sales. The same is true services that are not performed, in which case the facilities do not have the financial turnover. This means that tourism requires government policy to respond quickly in times of crisis, and therefore predetermines the role of Ministry which is responsible in tourism as extremely important for the further development of tourism and managing the effects of crises. The unpredictability of these externalities also hampers long-term efforts to maintain tourism infrastructure and employment in this sector. An effective management and regulation system enables a faster response to a negative situation by assigning roles and responsibilities to organizations, which can then develop emergency scenarios and specific procedures. It is important for the governments to engage in discussions with the private sector when developing anti-crisis measures. 
Table 1: Tourism GDP (direct) as \% of total GDP

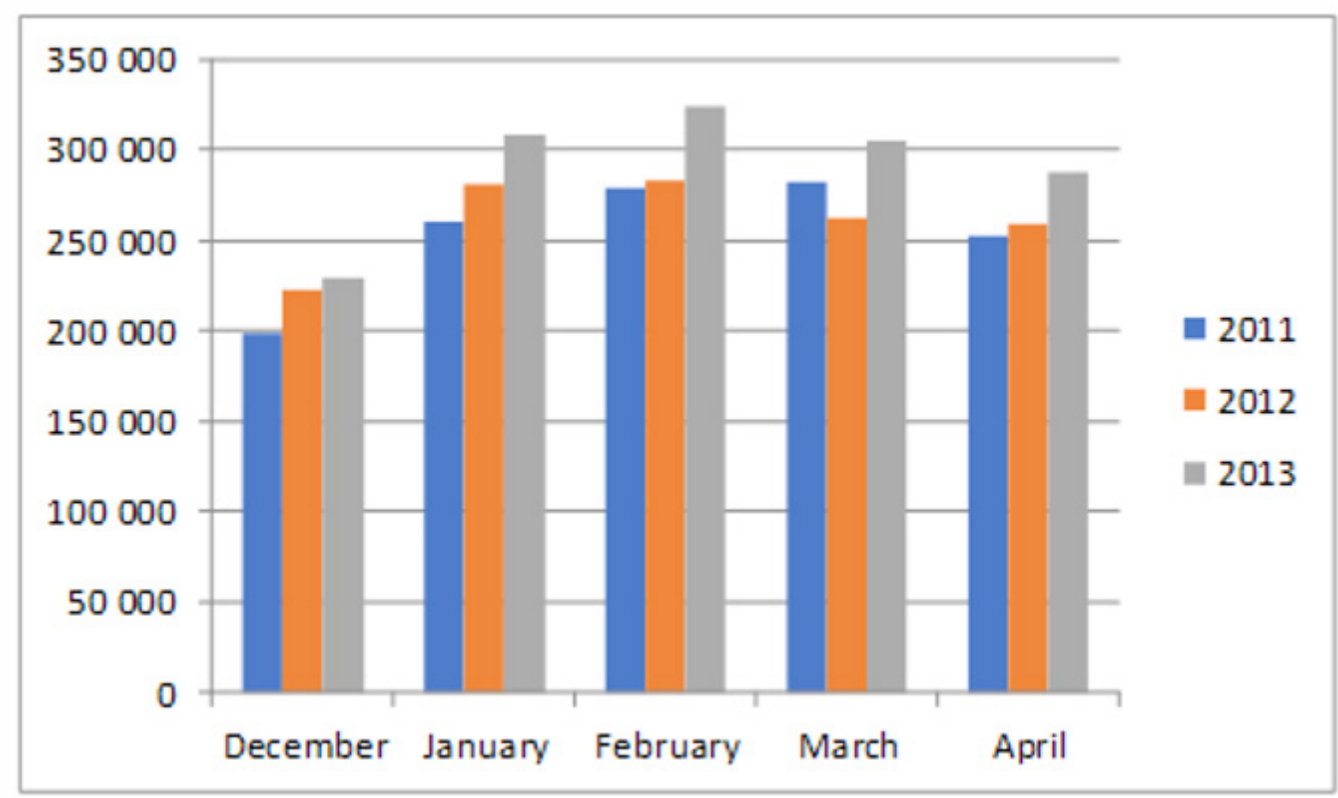

source: UELU Iourism slatisiles, $\angle U \angle U$.

Global tourism has been expanding for more than six decades. As a result of strong global economic growth and new markets, especially from Asia Pacific, the number of foreign tourists worldwide increased to more than $1,4 \mathrm{bn}$ in 2018 , an increse of $5,6 \%$ compared to 2017 . With the advent of international tourism before long-term growth is rising.

Tourism is influenced by a number of factors, including political situation, natural disasters, terrorism, civil unrest, or other unexpected events that take place in the country. No less serious threat, among the possible impending threats of instability, is political events for tourism, not only in the current time, but also in the future. The damaged image of the country also affects its destinations and the perception of tourists is corrected from negative to positive in the long run. A negative perception of the destination due to the tourist's concern for his safety during the stay results in a decrease in the number of visitors to the country.

The perception of the destination can also be in the context of cheap or expensive, but also safe or dangerous stay. If we add to all this the aspect of the tourism product, a service that is intangible and evaluated only on the basis of the recommendations of those who have already used it, the threat of reducing the number of incoming tourists multiplies. Damage to the destination's image in today's global world can sometimes be liquidating, especially for companies and sole traders doing business in a given area affected by the crisis.

According to the Global Code of Ethics for Tourism, which is a 
comprehensive set of basic principles aimed at guiding all actors involved in the development of tourism, e.g. governments, local communities, business and tourism professionals, foreign and domestic visitors, to develop tourism in a sustainable and responsible way, governments have a duty to inform about crises. In particular, this is addressed in Article 6 "Obligations of actors involved in tourism development":

(5) Governments have the right - and the obligation - to inform their nationals, in particular in the event of a crisis, of the difficulties or even dangers they may face during journeys abroad; however, it is their duty to provide such information in such a way that it does not unduly or exaggeratedly harm the tourism industry of the host countries and the interests of their own operators; the content of pre-travel advice should therefore be discussed in advance with the authorities of the host countries and with the professionals concerned; the recommendations made should be precisely proportional to the severity of the existing situations and specified in the geographical areas where the uncertainty has arisen; such advice should be considered or revoked as soon as the return to normal conditions allows (Perles-Ribes, et.al., 2016).

It is therefore clear that the crisis is having a major impact on tourism and its participants, and at the same time this importance of impact and impact must be accepted by governments. However, do governments, especially Slovakia, accept this obligation?

\subsection{The impact of crises from a historical perspective on the impact of tourism in Slovakia}

We can point out the effect of the impact of crises on tourism on other examples that directly affect Slovakia from a historical point of view. The first is a file with the code name Gorilla, which escaped and was considered the biggest corruption scandal of Slovak politicians. The political cause became public in December 2011. In early January 2012, Euroactiv wrote in an article on how a massive corruption scandal would mark the March (2012) parliamentary elections and shuffle politicians' cards. The Economist writes in its article of 27 January 2012 that this case is an unpleasant memory of the 1990s, when certain practices between politics and business operated in Slovakia. The worldfamous Financial Times mentions financial groups and the rewards they were supposed to receive for their support of politicians. Finally, the newspaper adds that Transparency International ranked Slovakia 66th in its Corruption Perceptions Index for 2011. Graph 4 presents the gradual decline in tourists, which culminated in March 2012 after the most massive protests over the Gorilla case. 
Graf 3: Inflow of tourists from abroad in the case of short-term stays for the years 2011 to 2013 always in the compared total number of tourists for the given month

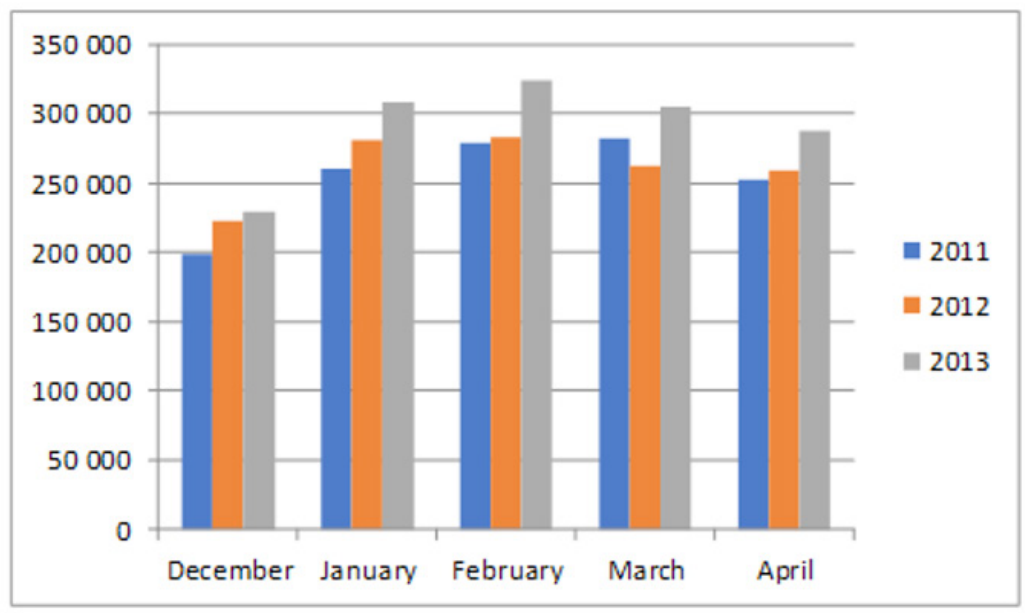

Source: EUROSTAT, 2020

The so-called liquid gold, called gas, flows through Slovakia from Ukraine. Here we move on to the second example. At the end of February 2014, unmarked soldiers armed with modern weapons appeared in the Ukrainian Crimea, who gradually occupied strategic positions and buildings during demonstrations against the new Ukrainian government. This resulted in a referendum on March 30, 2014 in Crimea, and at the request of Crimean Prime Minister Sergei Aksyonov, Russia sent troops to protect Russian citizens living in Crimea. This is a very simplified and quick interpretation of the situation, essential when comparing the impact of crises on tourism is that this situation has also affected Slovakia, which has seen a significant reduction in the number of tourists. This was also the official statement of the Ministry of Transport and the former SACR (Slovak Tourism Agency), which saw the lack of snow and the crisis in Ukraine behind the fall in 2014. 
Graph 4: Comparison of the development of the influx of tourists in the case of short-term stays retrospectively

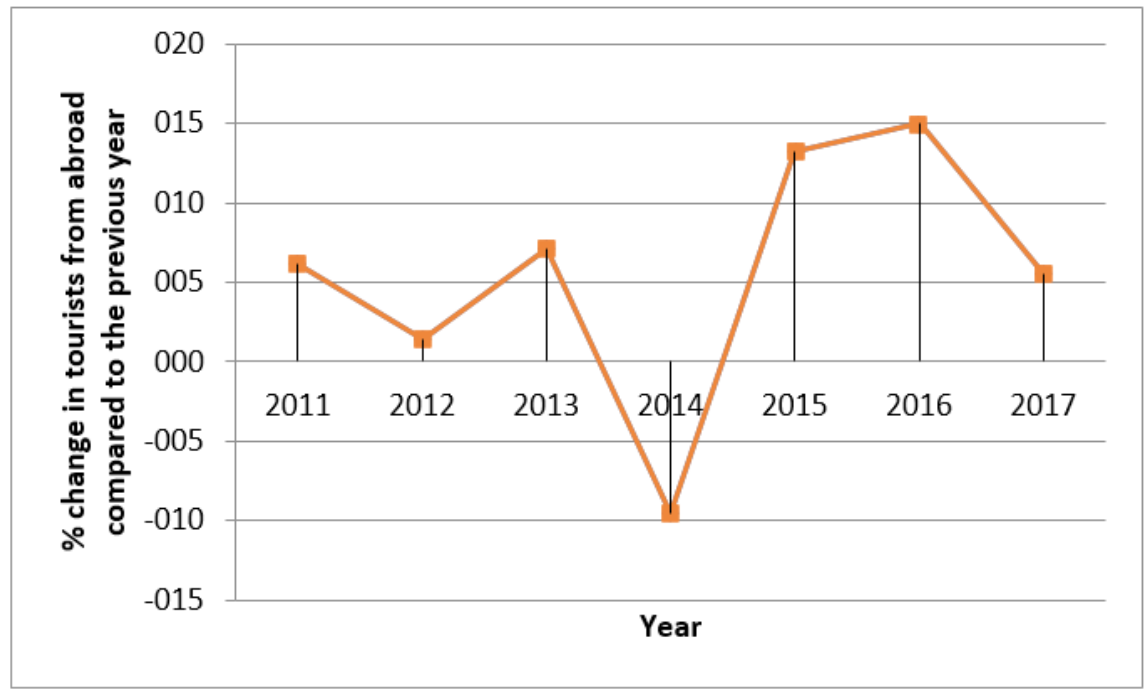

Source: Eurostat

Following the silent and infamous abolition of the SACR in the tourism sector in December 2016, destination management remained on the shoulders of tourism associations and organizations. Competences from the abolished agency were transferred to the Ministry of Transport and Construction, but in the case of communication on foreign markets, this was mostly saved by foreign authorities, diplomatic missions or the destination tourism organizations themselves. Working with a destination brand has never been so important. The development of tourism in 2018 was affected by another crisis, but there is no institution that would cover the communication and tried to prevent the negative impact of the political crisis as much as possible. The organizational unit at the Ministry of Transport and Construction, which did not have sufficient capacity after the abolition of the SACR, was unable to cope with this workload and this resulted in complaints from tourism organizations. The Government of the Slovak Republic, which emerged from the 2020 elections, declared in its Government Program Statement, which the Parliament approved in April this year, that it would re-establish the SACR. This could create a sufficient capacity background for effective marketing promotion of Slovakia as a travel market destination in foreign markets.

The crisis is a natural part of economic development and especially that which stems from the economic nature of the development of society. Predictive governments should also have in the case of a sector such as tourism built-in socalled. stabilizers in the form of state financial and institutional support, which would eliminate the negative impact of economic shocks. The crisis of tourism, 
caused by an epidemic and subsequently a pandemic, is already a crisis of a non-economic nature in terms of its causes, and it is necessary to expand the instruments of support measures for tourism development in compliance with safety epidemiological rules.

Graph 5: Without SACR, the started growth of tourism in the case of short-term stays of foreign tourists slowed down in 2017

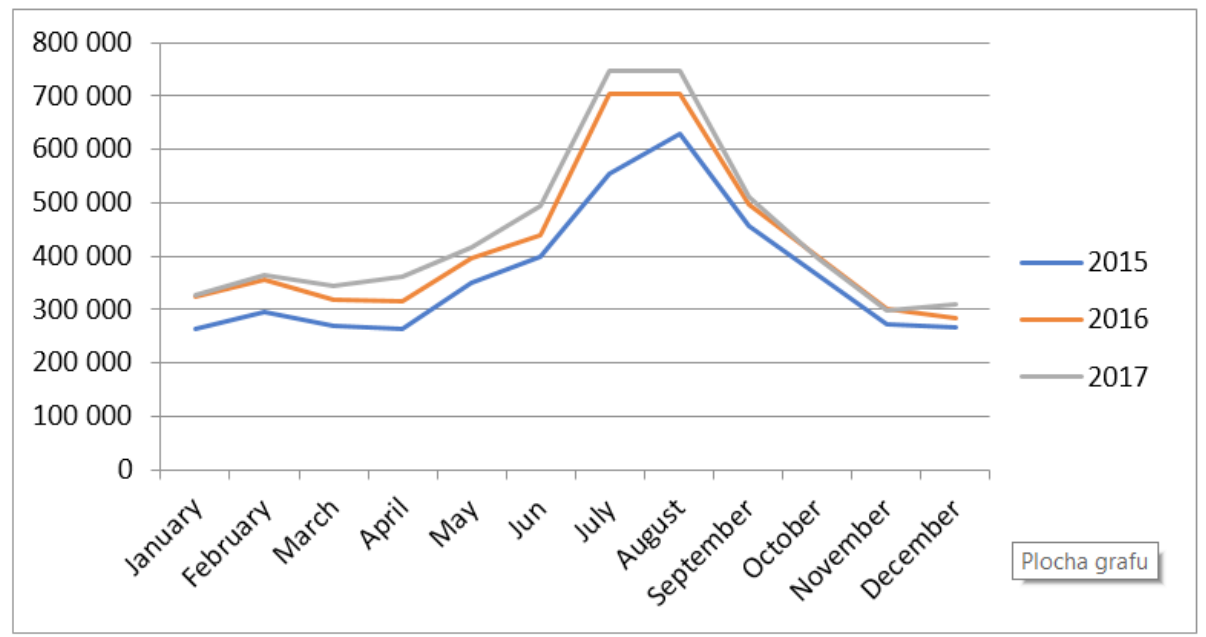

Source: EUROSTAT

\subsection{COVID-19 and consequences for tourism}

These days, we are witnessing a huge political, global but also economic change. More than 750,000 cases have been reported worldwide, including thirty thousand deaths as of April 1, 2020. Infected people are reported by more than one hundred and forty countries around the world. The World Health Organization officially declared COVID-19 (corona virus) as a pandemic on March 11, 2020, after much hesitation. But in many cases, the world's countries have encountered the virus much earlier. But what does $18 \%$ mortality say in all statistically terminated cases of patients with the virus? The corona virus is clearly changing the current world!

The current changes also affect the work system. More than 60 million people around the world are in crisis and governments are advised not to leave their homes at all, or to move out of their homes is completely banned. Many shops are closed and entrepreneurs do almost no economic activity. The world has stopped, so to speak. Governments are predicting declines in their economies in the tens of percent of GDP and are trying to create more economic measures as far as possible to eliminate the negative impact of the pandemic as much as possible. For tourism, the epidemiological crisis is even more serious 
than the economic crisis caused by economic reasons, whether on the supply or demand side. The greater threat to tourism in this case lies in the fact that the movement of people, which is immediately necessary for the attendance of tourist destinations, is limited. The negative economic demands of an epidemic crisis cannot be offset by virtual hoc-paid tours of museums, galleries or other cultural institutions.

The starting point to a large extent from the economic problem created by the pandemic may be domestic tourism and the use of Eurofunds and credit and guarantee schemes with a high degree of guarantee of their return. It may be possible, under very strict conditions, to use part of those resources from the EU structural funds that we cannot exhaust by the end of the current programming period. The EU has given us the echo that we can have around 2.5 billion available. euro Eurofunds, which we have been allocated for a very long time, we just do not know what to do with them. In total, we have about 4 billion unspent so far. euro, which means that we have only been able to use around $30 \%$ of the EU over the entire programming period. In April, the Slovak government decided to reallocate Eurofunds in favour of programs to combat COVID-19 and its consequences.

\subsection{Using Eurofunds to contain the effects of the crisis}

It is certainly not a way out of today's situation affected by the pandemic around COVID-19 and the restrictive measures of the Slovak government, it is abundantly to reallocate resources from Eurofunds between priority axes or non-operational programs, waste time and waste energy on something that later turns out to be a waste of opportunities. The current government elected in March 2020 under the leadership of Igor Matovič (OLANO) has just this tendency. The Deputy Prime Minister of the Slovak Republic for Investments and Informatization, Veronika Remišová, presented to the Government a material that will enable the transfer of Eurofunds in the amount of EUR 1.252 billion. The funds are intended for employment retention, business support and healthcare. Eurofunds are redirected to five areas, namely:

- 249.20 mil. EUR to support the health system,

- to maintain employment at 506.99 mil. EUR,

- aid of 330.20 mil. EUR for micro, small and medium-sized enterprises,

- to support the components of the integrated rescue system in the amount of 51 mil. EUR

- for other mitigation measures of COVID-19 amounting to 114.80 mil. EUR.

As a complement to the entire Eurofund financial mechanism, this makes sense, but it cannot be the focus. The release of Eurofunds for the 
implementation of smart cities technologies will bring significant funds to the economy, which will enable Slovak innovative companies to grow and increase their global competitiveness.

If there was ever a situation in tourism in Slovakia that would reduce visions and missions to clear lines, it is probably now. Discussions about the country's bucolic picture will not generate revenue, as has happened in the previous crises, which we pointed out in the previous chapter. Discussions about what developer and where he built the same do not have a positive impact. The only thing that will help is a sequence of events on the axis: data collection, analysis and synthesis, strengthening the system with the potential to support domestic consumption and finding USP Slovakia as a country that has something to offer the holidaymaker.

By increasing the comfort of local governments not only towards its inhabitants but also visitors, it will stimulate the desire to travel to these destinations. Perhaps also thanks to recreational vouchers, Slovaks can improve the financial situation in tourism, which will ultimately be reflected in the improvement of the entire economic situation of the Slovak population. The number of those who decided to spend a holiday at home rose by more than 15 percent year on year last year. Free days in some corners of Slovakia were preferred by 1.2 million locals. This was shown by overnight statistics from Eurostat.

More than two-fifths of Slovaks used the employer's support for their holidays. This was shown by the statistics of the Up Rekrea system. The average price of a stay last year was 2,019,308 euros. Of this amount, the employer paid the employee 170 euros. The holiday voucher can be used up to 275 euros. They are mandatory for companies with more than 49 employees. Only people who have worked for the employer for at least two years are entitled to them. And only for a holiday where they spend at least two nights in the accommodation.

So it is certainly not a way out of today's situation to floatically reallocate resources from Eurofunds between priority axes, or even operational programs, to waste time and waste energy on something that will later turn out to be a waste of opportunities. As a complement to the entire Eurofunds financial mechanism, this makes sense, but it cannot be the focus. However, it is necessary to focus on those mechanisms that are already applied and at the same time to support the drawing of those operational programs in which Slovakia is lagging behind and there is a risk that the country will have to return financial resources (Kóňa, 2020). 


\subsection{Smart cities as a tool to improve tourism}

Small and medium-sized enterprises, which represent the supply of intelligent industrial solutions of an innovative nature, should also play a role in creating the demand for their products and services by cities that want to embark on the trend of modern and innovative building of their development. The creation of formal and informal partnerships between businesses and cities could also create a demand for the sharing of multiple cities at the same time for concrete innovative solutions for the provision of public services to the population (Widhianthini, 2017).

Smart solutions at the city level can play a significant role in the development of innovation and digitalization in Slovakia and also contribute to meeting the goals of a carbon-free economy and use smart grid solutions to accelerate the use of renewable energy sources and thus affect a sustainable environmentally oriented economy (Kóňa, et.al., 2020).

To this end, it is necessary to use and develop new financial instruments for business development in this area using not only the direct resources of ESI Funds, but also the use of venture capital Slovak Investment Holding, grant and financial schemes Slovak Business Agency and financial support from the European Investment Bank and direct instruments of the European Commission in the framework of joint Community programs.

Two European smart tourism capitals for 2019 (Helsinki and Lyon) and 2020 (Gothenburg and Malaga) were selected through competition across the European Union. The European Capital of Intelligent Tourism is an EU initiative that recognizes the outstanding achievements of European cities as tourist destinations in four categories:

- sustainability

- availability

- digitalization

- cultural heritage and creativity (Corete, et.al., 2017).

This action supports the development of smart tourism in the EU by presenting exemplary practices of cities as tourist destinations. The aim of this initiative is to create a structure for the exchange of good practice between cities and to create opportunities for cooperation and new partnerships. The compendium of best practices implemented by cities also raises awareness of smart tools, initiatives and projects in the field of tourism and strengthens mutual learning between people and the innovative development of tourism in the EU. The initiative is managed by the European Commission. 


\section{CONCLUSION}

There has never been a better and more justified time to implement the smart cities agenda in Slovak municipalities. At the same time, however, there is a need for retrospective review of such implementations and their comparison. However, several key questions need to be answered:

- In which areas do specific municipalities need to implement smart solutions and how will they help tourism?

- Were the implemented intelligent solutions for self-government effective due to the evolution of time? Has the position of self-government improved? Have tourism indicators improved?

- Is there a more reasonable time to implement smart solutions than in the current corona crisis?

\section{REFERENCES}

DELlA CORTE, V., D’ANDREA, C., SAVASTANO, I., ZAMPARELli, P. (2017). Smart cities and destination management: Impacts and opportunities for tourism competitiveness. European Journal of Tourism Research, 17, 7-27. ISSN: 1994-7658

EUROSTAT (2020). Tourism. [online] Europa.eu. Available at: https:// ec.europa.eu/eurostat/web/tourism/data/main-tables [4 5. 2020].

KÓŇA. A., GUŤAN D., HORVÁTH. P.,(2020) Slovak Republic on the way to build Smart Cities based on KPIs with first Slovak Smart City Index. SciPap. Vol. 28. Issue 4.

KÓŇA, A. KÓŇA, J. 2020. Implementácia smart cities na Slovensku - potreba a východiskový stav. In : TRVALO UDRŽATEL'NÝ ROZVOJ V KRAJINÁCH EURÓPSKEJ ÚNIE II. ISBN 978-80-8152-855-2.

OECD (2010), OECD Tourism Trends and Policies 2010, OECD Publishing. ISBN: 978-92-64-07741-6

OECD (2012), OECD Tourism Trends and Policies 2012, OECD Publishing. http://dx.doi.org/10.1787/tour-2012-en

OECD (2020), OECD Tourism Trends and Policies 2020, OECD Publishing, Paris, https://doi.org/10.1787/6b47b985-en.

PERLES-RIBES, J.F., RAMÓN-RODRÍGUEZ, A.B., SEVILLA-JIMÉNEZ, M., RUBIA, A.

(2016). The effects of economic crises on tourism success: An integrated model.

Tourism Economics, 22(2), 417-447. ISSN: 1354-8166

WIDHIANTHINI. (2017). A dynamic model for sustainable tourism village planning based on local institutions. Journal of Regional and City Planning, 28(1), 1-15. ISSN: 2502-6429 